\title{
Investigation of the Noise Exposure in Weaving Workplaces in Western Turkey
}

\author{
Necla Yaman Turan ${ }^{1}$ (iD) 0000-0001-7432-4137 \\ Özcan Öney²* (DD 0000-0002-6232-2211 \\ ${ }^{1}$ Usak University/Faculty of Engineering/Textile Engineering Department, Usak, Turkey \\ ${ }^{2}$ UsakUniversity/ Faculty of Engineering/ Mining Engineering Department, Usak Turkey
}

Corresponding Author: Necla Yaman Turan, necla.yaman@usak.edu.tr

\begin{abstract}
Noise is an unavoidable problem in weaving workplaces. This problem has started to gain more importance with the speed increases in weaving machines. Working in noisy environments has become one of the most important elements in terms of public health with new regulations. Working at high noise levels prepares the ground for many health problems, especially hearing loss. In the study, the effect of technology differences in weaving machines and machine layout on noise level was investigated. Inthis study, noise levels in different weaving mills were investigated. First of all, noise maps were created in order to examine the distribution of existing noise levels in workplaces. Then, personal noise measurements were carried out and the results were discussed. It was seen that the placement of machinery along with machine technology had a great impact on noise level.
\end{abstract}

\author{
ARTICLE HISTORY \\ Received: 01.07.2020 \\ Accepted: 18.11 .2020
}

\section{KEYWORDS}

Noise, weaving, hearingloss, occupational health and safety.

\section{INTRODUCTION}

Noise pollution, namely environmental noise or sound pollution is the propagation of sound result in a very harmful impact on the human or animal life. Machines, transport, and propagation systems are the main reason for outdoor noise worldwide. Loom shed causes an excessive noise level of $94-99 \mathrm{~dB}(\mathrm{~A})$ based on the design, type, erection and number of looms used, condition of machines, fabric structure, building type, building size, etc. periodic in character [1]. When operating with a shuttle, noise level of a loom increases by about $1.5-2.0$ $\mathrm{dB}(\mathrm{A})$. Working in a work environment with high noise level for a long time has many negative impacts on human health. With the increase in mechanization and machine speeds, there has been an increase in noise levels and thus in noise-related health problems. It has negative effects on human health including the effects on hearing [2], physiological [3-6] and psychological effects. Although permanent hearing loss is one of the most important problems, it also causes many other problems including dyslexia, infertility and occupational accidents [2-6]. Sudden noises with the intensity of $140 \mathrm{~dB}(\mathrm{~A})$ cause trauma and prolonged exposure to noises above $90 \mathrm{~dB}(\mathrm{~A})$ gradually causes temporary and permanent threshold shifts. Hearing losses usually reach to the maximum level in 10-15 years $[2,7,8]$.

Sound, the source of noise, is a pressure wave and physical energy. An acoustic environment is needed for its propagation. General characteristics of sound waves can be given as frequency, amplitude, tone, timbre and intensity of sound [9].

Although an unpleasant noise, which has negative effects on people, differs from person to person, it is mandatory to use protective measures for noise above $85 \mathrm{~dB}(\mathrm{~A})$ in terms of Occupational Health and Safety [10]. The hearing threshold is $0 \mathrm{~dB}(\mathrm{~A})$ and the pain threshold is $120-130$ $\mathrm{dB}(\mathrm{A})$ [11]. Noise is performed in range analysis with $\mathrm{A}$ weighted equivalent and $1 / 1$ octave $[12,13]$. Noise sources are classified as plane source, point source, line source, indoor and outdoor sources [14]. Noises can be classified according to frequency content (simple, periodic, narrowbelt and wide-belt noise) and time-dependent variation of pressure (stable, unstable, impulse, burst, discrete and oscillating noise). Table 1 shows working times depending on noise level [15].

To cite this article: Yaman TN, Öney Ö. 2021. Investigation of the Noise Exposure in Weaving Workplaces in Western Turkey Tekstil ve Konfeksiyon 31(1), 27-33. 
Table 1. Working times depending on the noise level [15]

\begin{tabular}{lccccccc}
\hline $\begin{array}{l}\text { Noise level dB(A) } \\
\text { Maximum }\end{array}$ & 85 & 90 & 95 & 100 & 105 & 110 & 115 \\
workingtimes (h) & 8 & 4 & 2 & 1 & 0.5 & 0.25 & 0.125 \\
\hline
\end{tabular}

Values of ambient noise and personal exposure are measured according to TS ISO 1996 and TS EN ISO 9612, respectively [16,17]. In this context, various measuring instruments have been developed. In these quantitative measurements, many information from the noise caused at some point to the frequency distribution of the noise can be reached.

Negative effects of noise on people can be decreased by eliminating noise or by adjusting its levels to a comfortable level. The measures to be taken can be performed as reducing noise source, eliminating the reflection sources and blocking in the center of the receiver (on people) [18]. If the noise cannot be reduced from the source or reflection area, personal protective equipment must be used $[10,19]$. It is sufficient for ear protectors to reduce noise level to 75 $\mathrm{dB}(\mathrm{A})$. Since the possibility of accidents arising from not hearing warning signs in case of reducing noise level to lower levels, it should not be reduced lower than $70 \mathrm{~dB}(\mathrm{~A})$ $[18,20]$. Personal protective equipment should be selected by considering SNR values given in International Standard ISO 4869 [21].

It is beneficial to utilize noise mapping, which is often used in large plants with few workers, in industry in order to evaluate the risks of harmful noise or monitor noise in machine rooms [22]. Maps are used to measure the effectiveness of plans developed to reduce noise. They have two main purposes. The first aim is to determine the noisy areas and how many people are affected. The second aim is to determine the measures to be taken to reduce noise and prepare appropriate action plans [23]. The reasons of using software while preparing the noise maps can be listed as follows:

$\checkmark$ First of all, the noise at a certain point occurs as a result of noises from several different noise sources in many situations. Traditional measuring instruments cannot distinguish how much of the noise originates from which source.

$\checkmark \quad$ They are very useful in determining the measures to be taken to reduce noise. This is because they are dynamic models.

$\checkmark$ Noise maps prepared for certain time intervals can present average values of noise levels.

$\checkmark \quad$ The last reason is cost. Preparing the first map using such software not only reduces the cost but it also allows us to see the effects of the changes more quickly [23].

Since it is important to monitor noise in industry, utilizing more accurate and clarifying technique is essential to achieve this goal [24]. Being a tool for mapping and reporting of noise and any other type of measurements in work areas, NoiseAtWork was employed in this study.

In general, textile industry has a noise level of $80-85 \mathrm{~dB}(\mathrm{~A})$ except for weaving. In weaving sections, it is at 90-100 $\mathrm{dB}(\mathrm{A})$ level in loom shed depending on the automation of the machines and other conditions. Table 2 shows noise levels in loom sheds are given in.

Table 2. Noise levels in differentparts of a textile factory [1,25]

\begin{tabular}{llc}
\hline Department & Part & $\begin{array}{c}\text { Noise Level } \\
\text { (dBA) }\end{array}$ \\
\hline \multirow{4}{*}{ Yarn } & Blowroom & $80-83$ \\
& Carding & $84-89$ \\
& Draw frame & $84-88$ \\
& Cord & $82-86$ \\
\multirow{2}{*}{ Warping } & Ring & $86-90$ \\
& Winding & $82-86$ \\
Weaving & Warping & $80-86$ \\
& Sizing & $73-86$ \\
Finishing & Weaving (Non- & $94-99$ \\
& automated) & $95-97$ \\
\hline
\end{tabular}

The noise sources occurring in the weaving workplaces are caused by main engine, shedding, beat-up, and weft insertion systems. In addition to the constant and continuous noise of the main motor, the noise occurs in the other systems during shedding, beat-up, and weft insertion processes. As the weaving speeds increase, the frequency of operation of these systems increased, hence the noise level increased. There are three types of shedding systems in weaving machines. These can be given as cam shedding systems (negative and positive cam), dobby shedding systems (negative and positive dobby), jacquard shedding systems (single stroke-single roller, double stroke-single roller, double stroke-double roller, double stroke and double shedding) [26]. Weft insertion mechanisms can be listed as shuttle, projectile, rapier and air-jet. The fact that the systems are different not only increases the working speed of the machine but also affects the noise amount in the working environment.

In the study, five weaving workplaces including three in Usak Organized Industrial Zone and two in Karahallı which have different shedding, weft insertion mechanisms, as well as different technologies and workplace properties were determined. The noise levels of the factories will be evaluated according to the workplace layout and technological properties of the machines.

\section{MATERIAL AND METHOD}

\subsection{Machine and Workplace Properties}

In the selection of the workplaces to be measured, space properties holding the machines (area and volume per each machine, height), machine properties (number of machine, mean rpm of machines, capacities, etc.) and properties of 
the working environment (placement of the machines, number of machines the employees are dealing with, working time, etc.) were considered. Within the scope of the study, noise measurements were conducted in five different weaving workplaces having different weaving machines. In determining weaving machines, machines with different shedding and weft insertion mechanisms were determined and their noise levels will be evaluated. Mostly, the workplaces having jacquard, eccentric, dobby shedding systems and machines using shuttle, projectile, air-jet weft insertion systems were preferred. While all of workplaces were used standard construction materials (such as thickness, raw-material of wall), machine types of the workplace and the workplace information are as follows.

\subsection{Noise Measurement and Its Evaluation}

Noise measurements were conducted with CESVA SC 310 model noise measurement device according to TS ISO 1996-2“Acoustics - description, measurement and assessment of environmental noise - Part 2: Determination of environmental noise levels" method [16]. Ambient measurements are based on A weighted average. Noise measurement points were determined at a distance of at least 1 meter from the walls of the factory, at least 1.5 meters from windows or air gaps, at least 1 meter from other noise sources (weaving and spinning machines) and at least 2 meters between two points. A tripod is used to fix the device at a certain height from the ground in environmental noise measurements. The noise meter is placed $1.5 \mathrm{~m}$ above the floor. The measurements were performed at certain points representing the workplace and repeated three times, 5 minutes each. If the difference between the measurements is more than $3 \mathrm{~dB}$, the measurements are repeated. Noise at Work 2019.1 software was used in noise mapping and evaluation. Personal exposure measurements were conducted by using a CESVA DC 112 device according to TS EN ISO 9612 (2009) "Acoustics-Determination of occupational noise exposureEngineering method" [17]. Ambient measurements are based on a weighted average. Task-based measurements were carried out in the weaving workplaces. Personal sound exposure meter was fixed on the worker in a way that does not interfere with work and movement. Personal exposure measurements were made for eight (full day) hours as stated in the standard.

\section{RESULTS AND DISCUSSION}

Noise measurements were carried out in each workplace in accordance with the machine structure and its size. One hundred seven measurements were made at different points in workplace 1 (air-jet with jacquard/dobby looms) and the noise map of workplace 1 is given in Figure 1.

Table 3. Properties of the workplace and machines

\begin{tabular}{|c|c|c|c|c|c|c|c|c|c|c|c|c|c|}
\hline \multirow{3}{*}{$\begin{array}{l}\text { Workplace } \\
\text { No }\end{array}$} & \multirow{3}{*}{$\begin{array}{l}\text { Counts } \\
\text { of } \\
\text { Machine }\end{array}$} & \multicolumn{7}{|c|}{ Properties of Machine } & \multirow{3}{*}{$\begin{array}{c}\text { Fields of } \\
\text { Workplace / } \\
\text { Fields per } \\
\text { Machine } \\
\left(\mathbf{m}^{2}\right)\end{array}$} & \multirow{3}{*}{$\begin{array}{c}\text { Volume of } \\
\text { Workplace/ } \\
\text { Volume per } \\
\text { Machine } \\
\left(\mathrm{m}^{3}\right)\end{array}$} & \multirow{3}{*}{$\begin{array}{c}\text { Number } \\
\text { of } \\
\text { Worker }\end{array}$} & \multirow{2}{*}{\multicolumn{2}{|c|}{$\begin{array}{c}\text { Noise } \\
(\mathrm{dB}(\mathrm{A}))\end{array}$}} \\
\hline & & Model & \multicolumn{3}{|c|}{ Shedding } & \multicolumn{3}{|c|}{$\begin{array}{c}\text { Weft } \\
\text { insertion }\end{array}$} & & & & & \\
\hline & & & $\mathrm{J}$ & $\mathrm{D}$ & $\mathrm{E}$ & $\mathrm{A}$ & $\mathrm{G}$ & $\mathrm{P}$ & & & & Env. & Per. \\
\hline 1 & $\begin{array}{l}18 \\
6\end{array}$ & $\begin{array}{l}\text { Sulzer/Smit } \\
\text { Sulzer }\end{array}$ & $\mathrm{x}$ & $\mathrm{x}$ & & $\begin{array}{l}\mathrm{x} \\
\mathrm{x}\end{array}$ & & & $\begin{array}{c}1406.7 / \\
53.6\end{array}$ & $9846.9 / 410.3$ & 11 & $\begin{array}{l}92- \\
97\end{array}$ & 95.8 \\
\hline 2 & 34 & Dornier & $\mathrm{X}$ & & & $\mathrm{x}$ & & & $\begin{array}{c}1651.7 / \\
48.6\end{array}$ & $\begin{array}{c}11307.2 / \\
332.6\end{array}$ & 11 & $\begin{array}{l}95- \\
97\end{array}$ & 96.4 \\
\hline 3 & 30 & Sulzer & & & $\mathrm{x}$ & & & $\mathrm{x}$ & $\begin{array}{c}603.8 / \\
20.1\end{array}$ & $\begin{array}{c}4226.3 / \\
140.9\end{array}$ & 7 & $\begin{array}{l}93- \\
95\end{array}$ & 94.2 \\
\hline 4 & $\begin{array}{l}19 \\
3\end{array}$ & $\begin{array}{l}\text { Picanol } \\
\text { SAKM }\end{array}$ & & $\begin{array}{l}\mathrm{x} \\
\mathrm{x}\end{array}$ & & $\mathrm{x}$ & & $\mathrm{x}$ & $\begin{array}{c}1879.2 / \\
85.4\end{array}$ & $\begin{array}{c}13154.1 / \\
597.9\end{array}$ & 8 & $\begin{array}{l}95- \\
96\end{array}$ & 95.7 \\
\hline 5 & 17 & Bursa & & & $\mathrm{x}$ & & $\mathrm{x}$ & & $\begin{array}{c}121.8 / \\
7.2\end{array}$ & $\begin{array}{c}304.5 / \\
17.9\end{array}$ & 3 & $\begin{array}{l}97- \\
99\end{array}$ & 98.7 \\
\hline
\end{tabular}

(J: Jacquard; D: Dobby; E: Eccentric; A: Air Jet; G: Gripper Shuttle; P: Projectile)

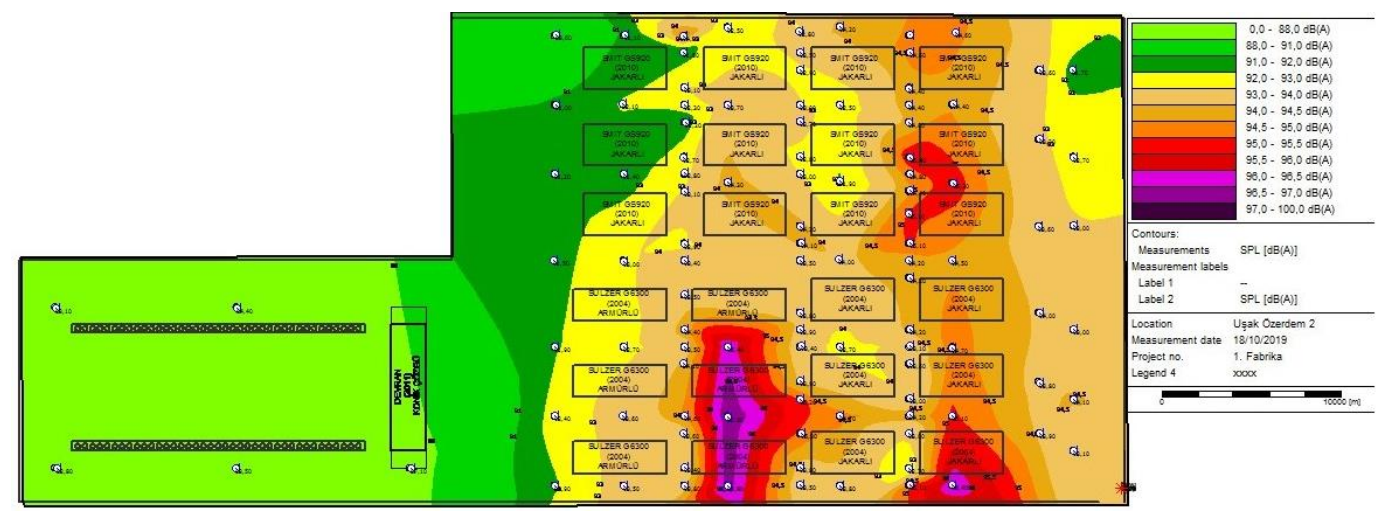

Figure 1. Noise map of the workplace having air-jet jacquard/dobby looms 
When the noise levels of the workplace 1 were examined, it was determined that while it varied between 92-97 dB (A) in the area where the weaving machines were placed, the noise level reduced to about $82 \mathrm{~dB}(\mathrm{~A})$ in the area where the warp releasing machine, which is a machine working much more quietly than weaving machines was located. The noise sources in Workplace 1 can be summarized as follows:

1. The engines of the machines were a constant source of noise.

2. The weft insertion system of all machines in Workplace 1 was air-jet. The most characteristic noise in this system was the sound caused by the high pressure air-jet during the throwing of the weft yarn. This periodic noise changes according to the working speed and width of the machine. Depending on the air pressure, the noise level also changed. The pressure applied to the yarns with smooth surface was lower.

3. While the noise level was about $95 \mathrm{~dB}(\mathrm{~A})$ in the areas where the Jacquard looms wereintense, the sound level reached to the highest values of about $97 \mathrm{~dB}(\mathrm{~A})$ in the dobby loom area. The reasons for the difference of 2 $\mathrm{dB}(\mathrm{A})$ between them can be given as follows.

a. The width difference in the looms $(2.60 \mathrm{~m}$ in dobby loom, $2.20 \mathrm{~m}$ in jacquard loom). Higher width means more pressure and more noise area in the weft insertion system.

b. Since the dobby and the machine were at the same level in dobby machines (2 sound sources), more than one sources caused more noise. Since the jacquard part of the machine was about $3 \mathrm{~m}$ above the machine in jacquard looms, the noise they form together was lower. The total volume of sound was more in jacquard machines and the sound propagation was more. Jacquard device was connected to the machine with wires and the sound waves hitting these wires propagatedand weakened. c. There was a lever for each frame that moves the frames on the dobby weaving machines. These mechanisms were another sound source for these machines. There is no such sound formation in the galleon threads in jacquard looms.

There were thirty-six measurements in workplace 2 (air-jet with jacquard looms). Its noise map is illustrated in Figure 2 .

It was seen that noise levels varied between $95-97 \mathrm{~dB}(\mathrm{~A})$ in the areas where weaving machines are located. The models, brands, and features (air-jet, jacquard) of all the machines in workplace 2 were the same. Therefore, noise differences in Workplace were caused by workplace layout. As can be seen in the workplace layout, the height of the gap (about 2 $\mathrm{m}$ ) located on the right side of Figure 2 was $5.5 \mathrm{~m}$ and the height of the other parts was $7 \mathrm{~m}$. On the other hand, there is a main layer of $2.5 * 2.5 \mathrm{~m}^{2}$ in the right-up side of the Figure 2.

The noise level at the right-bottom part of Figure 2 where the height was less being around $98 \mathrm{~dB}(\mathrm{~A})$. Sound propagated in waves and the noise felt occurred with the return of sound wave by hitting the surfaces. The reflection of sound waves by hitting the ceiling or the close walls was quicker, since the distance traveled by sound waves was short, the energy loss was less and the noise felt was higher. Besides, as seen in the sound intensity Equation (1), the noise increased as the sound energy coming to unit area increased. The machines located in the right-bottom part were placed closer to each other. Therefore, the sound energy coming to the unit area was relatively higher.

$$
\beta=10 * \log \left(\frac{E}{E_{0}}\right)
$$

\section{Equation (1)}

(E: Sound energy coming to a unit area $\left(\mathrm{W} / \mathrm{m}^{2}\right)$, Eo: The energy of the weakest sound that can be heard (10-12 $\mathrm{W} / \mathrm{m}^{2}$ )

Workplace 3 have eccentric and projectile looms and twentytwo measurements fulfilled in workplace 3 (Figure 3).
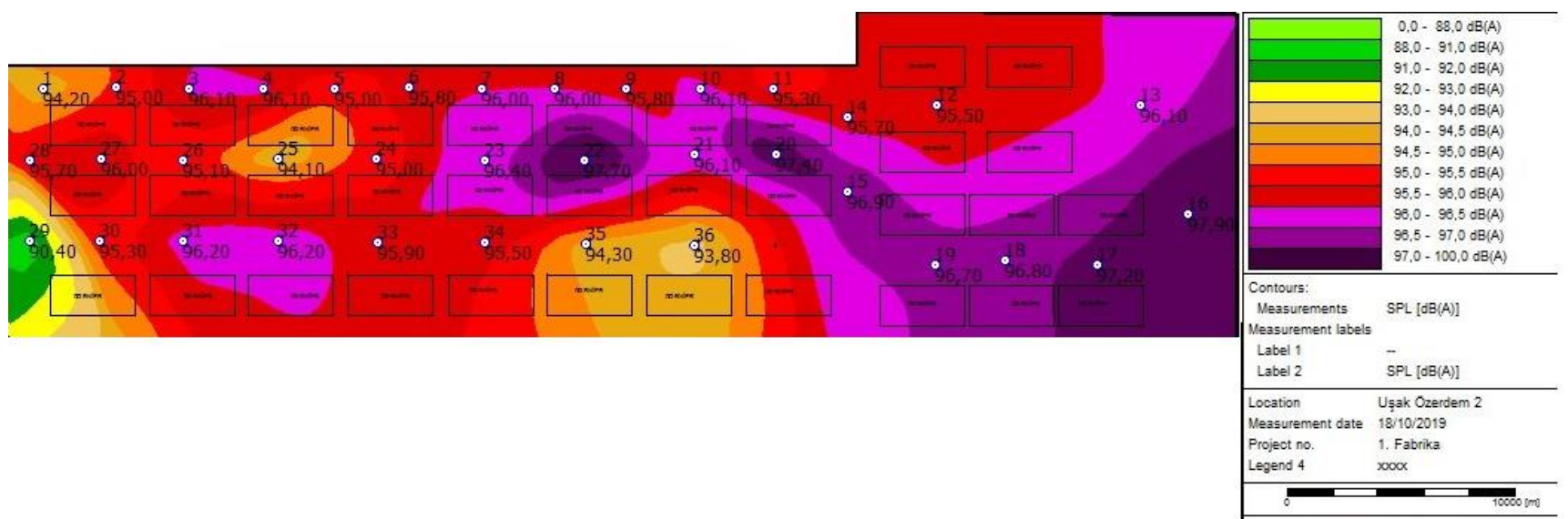

Figure 2. Noise map of the workplace having air-jet jacquard looms 


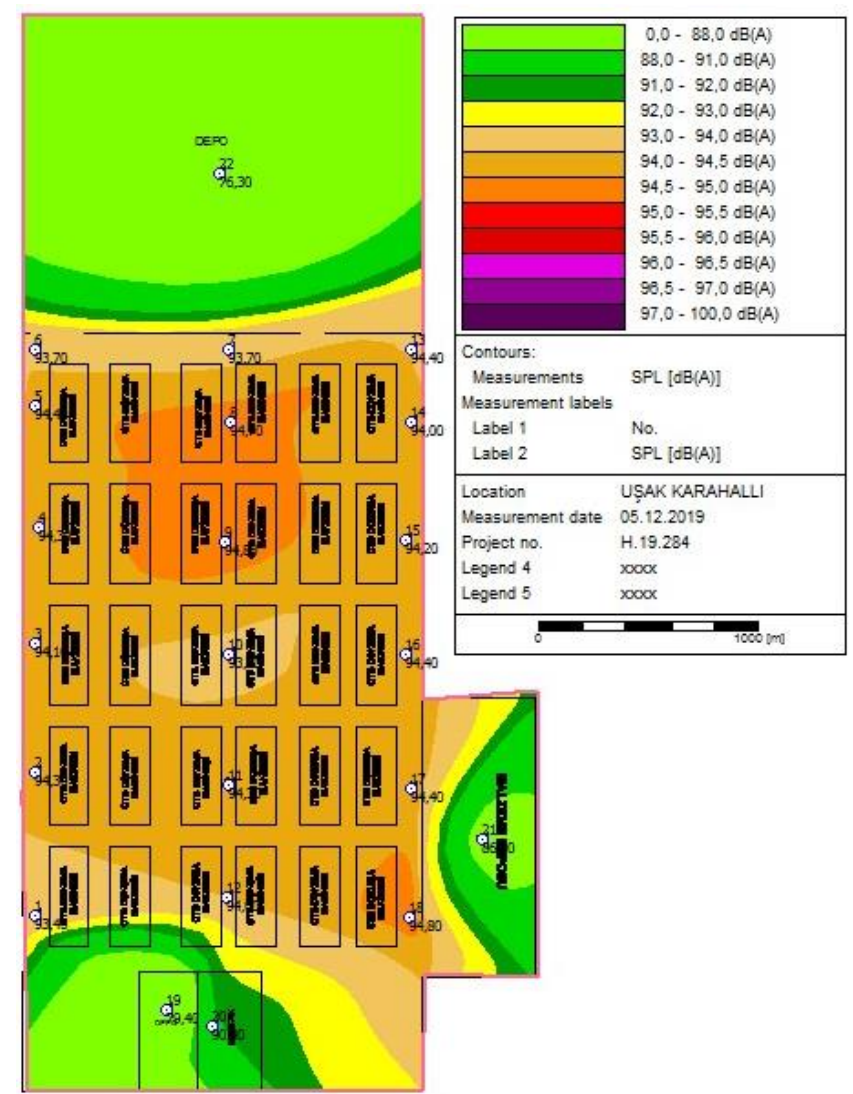

Figure 3. Noise map of the workplace having projectile-eccentric looms

From the Figure 3, noise level varying between 93-95 $\mathrm{dB}(\mathrm{A})$ was seen in the area where weaving machines were placed. In areas such as dining hall or warehouse within the workplace, the noise level gradually decreased. When the noise map of Workplace 3 was examined, it was observed that the sound level in the workplace was generally at the same level and the noise level was different only in two areas. It was higher (94.5-95 $\mathrm{dB}(\mathrm{A}))$ in one region and lower (93-94 $\mathrm{dB}(\mathrm{A})$ ) in another region. Since all the machines had the same properties, a machine-caused difference was not expected. The noise decrease according to edges is due to the distance from the sources. When the regions with high and low sound values were examined, it was seen that there was no physical formation that will create a different sound level. The difference in the sound level in these regions was due to a malfunction in the machines or the difference in the type of fabric woven.

Fifty-four measurements were carried out in Workplace 4 (dobby, projectile looms). Figure 4 shows its noise map.

When the noise map of Workplace 4 was examined, it was seen that there were distinct differences between the noise levels of the weaving machines with the areas where warp and fabric control machine, having less noise level, was placed. It is seen that the noise levels raised to 95.5-96 $\mathrm{dB}(\mathrm{A})$ levels in the middle sections of weaving machines, the noise levels gradually decreased from their middle sections to the edges, and the noise levels decreased down to $88 \mathrm{~dB}(\mathrm{~A})$ in the areas where the warp machine was placed and in the closed areas. This indicated that the noise level decreased as we moved away from the sound sources and when the number of sound sources decreased. The noise level at certain points in the workplace was caused by the malfunctions of the machines in that region or weaving of different fabrics. It is normal that the noise level was low in the area where three SAKM machines were placed in the workplace. This noise is due to the technological features of picanol and SAKM brand machines.

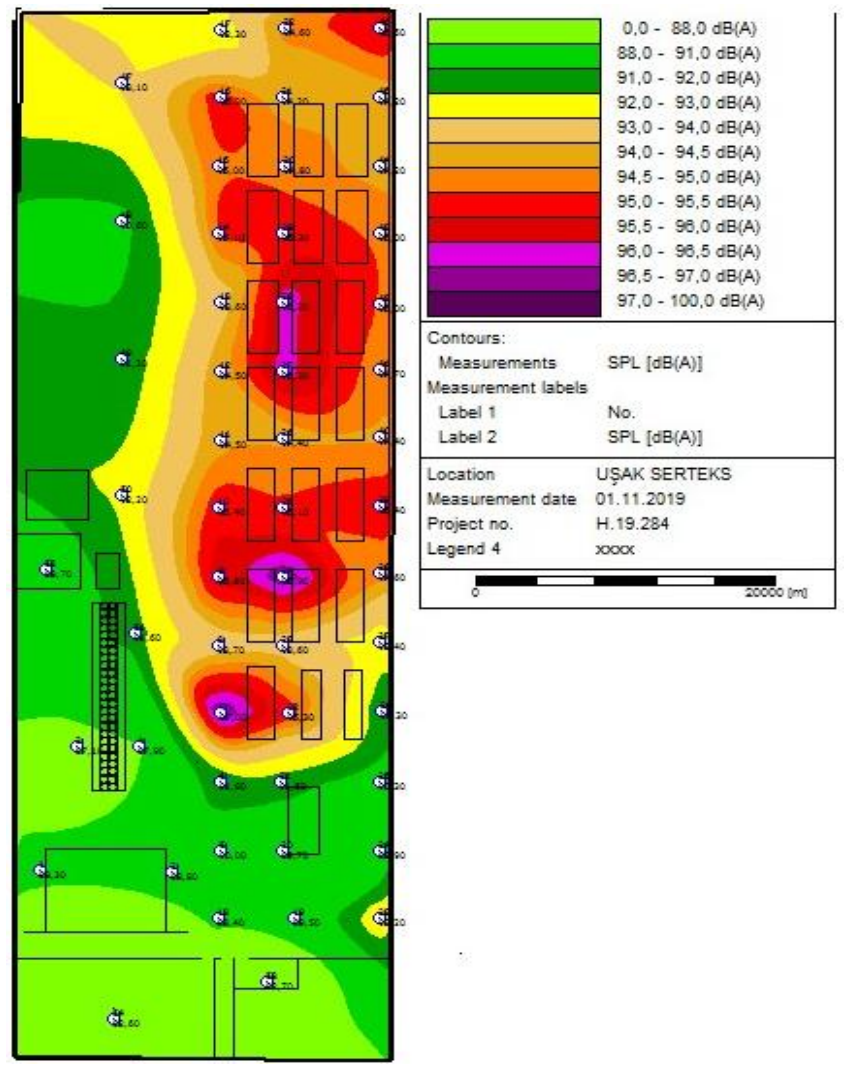

Figure 4. Noise map of the workplace having dobby and projectile looms

The reasons for low noise level of SAKM machines:

1. The speed of the SAKM machine is lower than that of the Picanol Weaving machine.

2. The working width of the SAKM machine is lower than that of the Picanol machine.

3. While SAKM weaving machines have a rapier weft insertion mechanism, picanol looms have an air-jet weft insertion mechanism. The noise generated by rapier weft insertion mechanism is lower.

4. Shedding mechanism is mechanical dobby in SAKM machines, whereas it is rotary dobby in picanol machines. The noise of rotary dobby mechanism is lower due to reduced swing motion. However, this difference is not so big.

Eight noise measurements were made in the fifth workplace, which is very small $\left(304.5 \mathrm{~m}^{3}\right)$ and has very old technology. Noise map is given in Figure 5. 


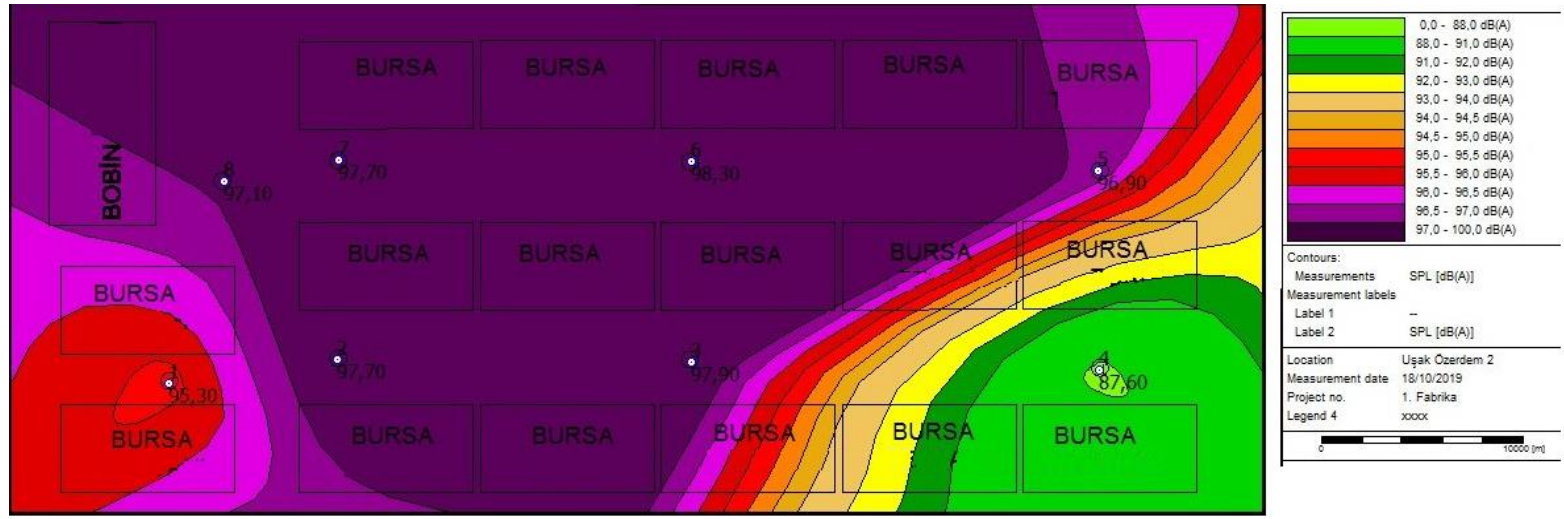

Figure 5. Noise map of the workplace having eccentric gripper shuttle

As it can be seen from Figure 5, noise levels changed between 97-99 $\mathrm{dB}(\mathrm{A})$ range. The reason for formation of red parts in the right of the figure is the shuttle installation process during measurement and the weavers waiting for this process. Since these times are constantly present in the Workplace condition, the measuremets at these points were not eliminated. Even a single missing source shows its effect on noise level. The reasons of having higher noise sources of shuttle looms found in the workplace compared to the other machines can be shown as;

1. Since the machines are 1960 models, they are a serious source of noise because of the shedding system.

2. Weft insertion mechanism is the main reason for the sound of these machines. Since the acceleration value applied for increasing the speed of shuttle having a weight of approximately 400-500 g from constant conditions to an approximately $5 \mathrm{~m} / \mathrm{sec}$ speed (about 0.1 second) is high, a high amount of noise occurs during beat-up. The braking process applied on the opposite side of the machine to decrease the speed of the shuttle launched to zero in a very short time also caused this noise to increase.

There are 3 basic ways to reduce the noise. These are eliminating the noise from its source, blocking the propagation of the noise and taking protective measures against the noise in the receiver [18]. The measures that can be taken in the said workplaces are given below:

$>$ Eliminating the sound from the noise source or isolating the sound source are not seen to be possible for weaving workplace. Because noise sources are an integral part of the machine. Regular maintenance should be carried out to eliminate the causes of extra noise. Modernization also slightly lowers the noise level (difference between the Workplace 5 and others).

$>$ The elimination of the noise in the propagation ways can be made by using isolated wall-floor-ceiling materials and using barrier. In this study, simulations were performed using the variables of height, thickness and materials of barrier in the program used. But, effective results couldn't be obtained with this programme.

$>$ Even when a coefficient of the materials used in the ceiling-floor-walls in the noise mapping program used is chosen as the values close to $1(\mathrm{a}=1$ perfect sound absorber, $\mathrm{a}=0$ perfect sound reflector materials), no significant change was observed in the noise map.

$>$ Preventing noise in the receiver can only be achieved by personal protective equipment. Personal protective equipment should be used so that the hearing levels of the workers do not fall below $75 \mathrm{~dB}$ (A). Since the noise level in each workplace is over $85 \mathrm{~dB}$ (A), personal protective equipment must be absolutely used. It will be sufficient to use an ear plug having a value of 20 SNR.

\section{CONCLUSION}

The distribution of noise levels inside the factories were examined with this article. When the noise results were evaluated, the technologies of the machines, the weft insertion mechanism, the shedding mechanism, and the placement of the machines are the most important parameters in the noise level. Measurements in all the textile workplaces showed that noise levels had significant values and a great importance in terms of occupational health and safety to the workers. So, it is recommended to make noise mapping in textile workplaces and to determine the high noise levels inside the factories before occupational noise measurements of workers to be measured. In accordance with the results, the speed increase in the machines affects the noise level negatively. As the distance between the machines and the machine-wall decreases, the noise level increases. As the volume per machine decreases in the environment with the same noise sources, the noise level increases (Workplace 2). Noise levels of weaving machines having dobby shedding mechanism are higher than weaving machines having jacquard shedding mechanism (Workplace 1). The noise level in rotary dobby machines is lower than the mechanical dobby machines (Workplace 4). The noise levels in weft 
insertion mechanism decrease in shuttle, air-jet and rapier (projectile), respectively. Weaving width, frequency, number and smoothness of yarn affect the noise level. Regular maintenance of the machines prevents the formation of malfunction-originated noise. The use of barriers in closed areas that are close to each other or have equal noise sources has no positive effect on noise. Insulated wall-floor-ceiling materials did not have a significant effect on noise level.

Considering the above results, by increasing the area / volume per machine and decreasing the number of noise sources per unit area in weaving workplace with high noise levels, the noise level may decrease. On the other hand, taking into account the values in the noise maps, shortening the working hours of the employees and to be operated elsewhere (such as working in a less noise environment after a while) can be considered as a protective measure. Additionally, in order to prevent workers from being negatively affected by noise, the measures that can be taken include using ear plugs with 20 SNR value in accordance with the regulation and having them worked with rotation as far as possible.

\section{REFERENCES}

1. Talukdar MK.2001. Noise pollution and its control in textile industry. Indian Journal of Fibre and Textile Research 26, 44-49.

2. Erdoğan A. 2016. Denizli'de üç tekstil fabrikasındaki gürültü düzeyinin çalışanlar üzerine etkisi. Pamukkale Üniversitesi, Tıp Fakültesi, Halk Sağlığı Anabilim Dalı, Uzmanlık Tezi, Denizli, Turkey.

3. Işık E. 2019. Hidroelektrik enerji santrallerindeki gürültü düzeyinin çalışanlar üzerine psikososyal etkilerinin araştırılması. Avrasya Üniversitesi, Sağlık Bilimleri Enstitüsü, İş Sağlığı ve Güvenliği Anabilim Dalı, Doktora Tezi, Trabzon, Turkey.

4. Schneider E. 2005. Risk observatory, thematik report: Noise in figures. Belgium: European Agency for Safety and Health at Work.

5. Lusk SL, Gillespie B, Hagerty BM, Ziemba RA. 2004.Acuteeffects of noise on blood pressure and heart rate Archives of Environmental Health: An International 59(8), 392-399.

6. https://www.ilgltd.com.tr/2016/10/10/gurultunun-insan-sagligiuzerine-etkileri/

7. http://www.dataakademi.com.tr/wp-content/uploads/2017/02/38MESLEK\%C4\%B0-\%C4\%B0\%C5\%9E\%C4\%B0TMEKAYIPLARI.pdf

8. https://www.ttb.org.tr/STED/sted0700/5.html

9. http://koklea.tripod.com/ses.htm

10. https://www.resmigazete.gov.tr/eskiler/2013/07/20130728-11.htm

11. Çevresel Gürültü Ölçüm ve Değerlendirme Klavuzu. 2011. T.C. Çevre ve Şehircilik Bakanlığı. Ankara, Turkey.

12. TS 854.1970. Ses veya gürültünün güç ve yeğinlik (şiddet) seviyelerinin ifadesi.

13. Ege F, Sümer SK, Sabanc1 A. 2003.Tekstil fabrikalarinda gürültü düzeyi ve etkileri Türk Tabipleri Birliği Mesleki Sağlık ve Güvenlik Dergisi Temmuz, 30-39.

14. https://www.metalurji.org.tr/dergi/dergi127/der127_22.pdf

15. https://www.resmigazete.gov.tr/eskiler/2013/07/20130716-2.htm

16. TS ISO 1996-2. Acoustics - Description, measurement and assessment of environmental noise - Part 2: Determination of environmental noise levels.

17. TS EN ISO 9612. 2009. Acoustics - Determination of occupational noise exposure - Engineering method

18. Öz IO. 2018.Tekstil sektöründe termal konfor, aydınlatma, gürültü ölçümleri ve alınacak önlemlerin değerlendirilmesi. Uşak Üniversitesi, Fen Bilimleri Enstitüsü, İş Sağlığı ve Güvenliği Anabilim Dalı, Yüksek LisansTezi. Uşak Turkey.

19. https://www.resmigazete.gov.tr/eskiler/2012/06/20120630-1.htm

20. http://www.afterhourslive.org.uk/wp-content/uploads/2017/11/ Sound-Advice.pdf

21. https://istanbulvizyonosgb.com/kkd/kulak-koruyucularin-secimi-venitelikleri/

22. http://www.noise-measurement.nl/map-industry-indoor.html

23. https://www.tankutaslantas.com/gurultu-kontrol-yontemleri-vegurultu-haritalari-uzerine-bir-uygulama/

24. Majidi F, Rezai N. 2016. Study of noise map and its features in an indoor work environment through gis-based software Journal of Human Environment and Health Promotion 1(3), 138-142.

25. Uğurlu F. 2011. Tekstil sektöründe işsăğl̆ğl ve güvenliği. İş Müfettişi Yardımcılığı Etüdü. Çalışma ve Sosyal Güvenlik Bakanlığı İş Teftiş Kurulu Başkanlığı, Adana.

26. Abdullayev G, Soydan AS, Hasçelik B. 2003. Dokuma makinelerinde ağızlık açma mekanizmaları: Bölüm 1-İnceleme Pamukkale Üniversitesi Mühendislik Fakültesi Mühendislik Bilimleri Dergisi 9(1), 103-113. 